5. Historia de los Derechos patrios de américa 

Revista de Estudios Histórico-Jurídicos

[Sección Historia de los Derechos Patrios de América]

XXXV (Valparaíso, Chile, 2013)

[pp. 431 - 459]

\title{
EL ESTATUTO JURÍDICO DE LOS INDÍGENAS EN LAS CONSTITUCIONES HISPANOAMERICANAS DEL PERÍODO DE LA EMANCIPACIÓN
}

[The Legal Statute of the Indigenous Peoples of the Hispanic Constitutions of the Emancipation Period]

\author{
Jesús Luis Castillo Vegas* \\ Universidad de Valladolid, España
}

\begin{abstract}
RESUMEN
El trabajo expone las distintas políticas que las constituciones hispanoamericanas, tras la Independencia de la metrópoli, adoptaron con respecto a los indígenas. Los planteamientos constitucionales incluyen bien una política de exclusión, que trata al indígena como un extranjero, bien una política paternalista, continuadora de la mantenida durante el período colonial, bien una política de rigurosa igualdad. Sin embargo, la política más frecuentemente consagrada en estas constituciones fue la dirigida a la asimilación.
\end{abstract}

Palabras Clave

Constituciones hispanoamericanas Población indígena.

\begin{abstract}
This work outlines the different policies that the Hispanic American constitutions adopted with regard to the indigenous peoples after the Independency of the metropolis. The constitutional statements include an exclusion policy, that treats the indigenous peoples as foreigners, a paternalistic policy, that maintains the policy that prevailed along the Colonial period, and a policy of strict equality. Nonetheless, the policy towards assimilation was the one most frequently enshrined in these constitutions.
\end{abstract}

\section{Keywords}

Hispanic American constitutions Indigenous population.

RECiBIDO el 24 de junio y ACEPTADO el 1 de julio de 2013

* Profesor de la Facultad de Derecho de la Universidad de Valladolid. Dirección postal: Universidad de Valladolid, Facultad de Derecho, Plaza de la Universidad, 47002, Valladolid, España. Correo electrónico: castillo@der.uva.es 


\section{LAS POLÍTICAS CONSTITUCIONALES SOBRE LOS INDÍGENAS}

Las constituciones hispanoamericanas ${ }^{1}$ que, en la segunda y tercera década del siglo XIX, plasmaron la independencia de las antiguas colonias recogieron en sus textos el espíritu de libertad que transmitieron las revoluciones de los Estados Unidos, de Francia y de Haití, así como los ideales liberales que los españoles peninsulares y americanos sustentaron en el proceso que lleva a la Constitución de Cádiz. De esta manera, el constitucionalismo hispanoamericano puso fin a la monarquía, la Inquisición, el tormento, la trata de esclavos, los mayorazgos, etc.

En esos textos se descubren influencias muy diversas, donde se mezclan los ideales democráticos, republicanos, liberales y conservadores. Son textos eclécticos, con elementos no siempre bien amalgamados, por lo que encontramos, por ejemplo, en la misma constitución artículos de clara influencia rousseauniana junto a la declaración de que la religión católica es la única del Estado, o la afirmación más encendida de la libertad de imprenta junto a la censura eclesiástica. Sólo el común interés de mantener la unidad para garantizar la independencia frente a la metrópoli puede explicar la singular simbiosis de ideas conservadoras, liberales, republicanas y democráticas que conviven en estos textos constitucionales.

Por nuestra parte, vamos a limitar este trabajo al examen de los principales cambios que estas constituciones introdujeron con respecto a la población indígena, y, de manera muy especial, a la supresión del tributo indígena y de los trabajos personales, así como a la obligación de repartir las tierras anteriormente poseídas de manera comunitaria. Si nos fijamos en los cambios introducidos sobre estas materias se puede afirmar que, entre las ideologías concurrentes, fue la liberal la que conseguiría imponerse, pues son los intereses de la nueva burguesía criolla quienes más se favorecieron con la implantación de una economía basada en el dinero, en el intercambio voluntario del trabajo y en la expansión de la propiedad privada.

Conforme se fue asentando la independencia y se elaboran los nuevos textos constitucionales hispanoamericanos encontramos varias maneras de abordar la relación de las nuevas repúblicas con la población indígena. Si nos fijamos en las constituciones que aparecen desde 1811 hasta aproximadamente 1830 en las antiguas colonias españolas podemos reconocer cuatro planteamientos diferentes, aun admitiendo que muchas de ellas son difíciles de clasificar porque participan de varias políticas a la vez:

\section{Política de exclusión.}

Una primera consideración constitucional con respecto a los indígenas consistió en considerarlos como extranjeros. El indio fue visto como un ser extraño

\footnotetext{
${ }^{1}$ Las constituciones hispanoamericanas son fácilmente accesibles en Internet. Salvo cuando se indica otra cosa, hemos utilizado la web de la Biblioteca Virtual Cervantes: http://bib.cervantesvirtual.com/portal/constituciones/constituciones.shtml (abril 2013). Para las constituciones de las provincias colombianas resulta útil la compilación realizada por OrLANDO Melo, Jorge, Documentos constitucionales colombianos, 1810-1815, en: http://www.jorgeorlandomelo.com/ bajar/documentosconstitucionales1.pdf (abril 2013).
} 
a la propia comunidad, alguien de fuera aunque esté dentro de "nuestro territorio". No es que se considere a las tribus indígenas como Estados extranjeros. Los tratados que pueden llegar a realizarse no son vistos propiamente como tratados internacionales. El llamado "territorio indio" es sólo un cuerpo extraño, destinado incluso a desaparecer. Podríamos situar dentro de este primer bloque a todas aquellas constituciones que no dicen nada sobre la población indígena, que no la "ven" a nivel constitucional.

Sorprende que un buen grupo de estas constituciones no haga mención alguna sobre la población indígena. Constituciones como la de Cundinamarca de 1811, la mejicana de Apatzingán de 1814 o la Constitución Vitalicia de Perú de 1826, simplemente no se refieren a los indios ${ }^{2}$. Se podría entender que los redactores criollos de los textos constitucionales hubieran relegado a la población indígena a la condición de una minoría, aun cuando constituían de hecho la mayoría de la población ${ }^{3}$, pero es que simplemente no aparece ninguna referencia.

Esta ausencia constitucional podría interpretarse como una deliberada inclusión de la población indígena entre los ciudadanos, o sea, como la consciente decisión de darles a todos los habitantes exactamente el mismo trato de ciudadanos. Sería posible pensar que no se hace ninguna referencia porque se pretende dar exactamente la misma consideración a todas las castas y colores, que no se menciona a blancos, indios, negros y mestizos precisamente para evitar cualquier discriminación. Obviamente es mejor que la constitución no diga nada, sobre todo cuando la referencia expresa sirve para excluir a una parte de la población del disfrute de sus derechos.

Es sabido que cuando la Constitución de Cádiz se ocupa de la minoría negra, de los "habidos y reputados por originarios del África", lo hace justamente para discriminarles, afirmando de manera paradójica que se deja "abierta la puerta de la virtud y del merecimiento para ser ciudadanos" en el mismo momento en que se les niega la ciudadanía ${ }^{4}$. Pero la ausencia de referencias a las etnias en modo alguno admite una interpretación tan benévola. En algunos casos, la falta de artículos constitucionales sobre la población indígena forma parte de la exclusión que cabe atribuir a la mentalidad de quienes elaboran las constituciones, del mismo modo en que fueron excluidas de la ciudadanía las mujeres sin necesidad de decirlo explícitamente.

Así, la Constitución de los Estados Unidos de Norteamérica, que sirve de inspiración a algunas iberoamericanas ${ }^{5}$, es un ejemplo de esta tácita exclusión. La

${ }^{2}$ Tampoco se hace referencia a los pueblos indígenas en la Constitución quiteña de 1812 , en las Constituciones politicas de Bolivia de 1826 y 1831; en las Constituciones de Chile de 1823 y 1828, o en la Constitución de las Provincias Unidas del Centro de América de 1824.

${ }^{3}$ Debe quedar claro que, como precisa DE LuCAS, Javier Sobre algunas dificultades de la noción de derechos colectivos, en ANSUÁTEGUI ROIG, Francisco Javier (editor), Una discusión sobre derechos colectivos (Madrid, 2001), pp. 157-166, las minorías no se definen por el número de sus integrantes, sino por la situación de dominación a la que están sometidas, de tal forma que podría haber, como era el caso de muchos países de Hispanoamérica, mayorías minoritarias.

${ }^{4}$ Constitución española de Cádiz (1812), tít. $2^{\circ}$, cap. $4^{\circ}$, artículo 22.

${ }^{5}$ Véase: Simmons, Merle, La revolución norteamericana en la independencia de Hispanoamérica (Madrid, 1992). 
población indígena no fue convocada al proceso constituyente, no se la tuvo en cuenta para calcular la población que debía votar y, en alguna ocasión, se disponen preceptos como los relativos al comercio con las "tribus de indios" lo que supone la consideración de los mismos como pueblos extraños, pero no como ciudadanos. La Constitución estadounidense de 1787 atribuye competencias al Senado respecto al comercio con las tribus de indios, pero los indígenas, que no pagan impuestos, son descartados a efectos de la representación política. "Con el propósito en cambio de expandirse a costa de los pueblos indios, éstos no podían contemplarse por los Estados Unidos ni como extranjeros ni como nacionales propios" ${ }^{\text {. }}$.

También entre las constituciones emancipadoras hispanoamericanas encontramos algún caso en el que los indios son asimilados a las naciones extranjeras. Así el Acta Constitutiva de la Federación Mexicana de 1824, al fijar las competencias exclusivas del Congreso, incluye la de "arreglar el comercio con las naciones extranjeras y entre los diferentes estados de la federación y tribus de indios"7. Se trata de constituciones que se refieren a los indios como tribus errantes que ocupan un territorio impreciso y que se considera "deshabitado" precisamente por el carácter nómada de esas tribus. Entre los muchos requisitos que estas constituciones exigen para el pleno disfrute de la ciudadanía está el de ser nacional, pero no basta para ello haber nacido dentro del territorio, sino que hay que estar domiciliado, o sea, hay que ser vecino, por eso, conforme a la Constitución gaditana, no serían considerados españoles los gitanos que viven trashumantes. Y esta es la condición de algunos pueblos indios que se hallan en las fronteras; de ahí que, a veces, se les utilice para delimitar el territorio nacional.

Por ejemplo, en la Constitución de Popayán, en el antiguo Reino de Nueva Granada, se señala a las "naciones bárbaras Andaquíes" para determinar el territorio nacional de esta provincia de Popayán ${ }^{8}$. El territorio que ocupan aquellas tribus indígenas que vagan errantes entre distintas provincias no es el territorio de otro Estado, ni se considerará que sus ocupantes tengan verdadera propiedad sobre el mismo. En el Acta de la Federación de las Provincias Unidas de Nueva Granada de 1811 se habla de "tierras baldías", de territorios inhabitados, de res nullius, que "por estar inhabitadas y fuera de los limites conocidos de las mismas provincias", son consideradas como inhabitadas por carecer de población fija'. Por eso, después de decir que están inhabitadas reconoce que viven en ellas naciones errantes. Con respecto a esos pueblos en dicha Acta se establece: "No por esto se despojará ni se hará la menor vejación o agravio a las tribus errantes o naciones

${ }^{6}$ Clavero, Bartolomé, Ama Llunku, Abya Yala: Constituyencia indígena y Código ladino por América (Madrid, 2000), p. 25. La concesión de ciudadanía a la población indígena de los Estados Unidos no se producirá hasta 1924 y precisamente para evitar las interferencias extranjeras.

${ }^{7}$ Acta Constitutiva de la Federación Mexicana (31 de enero de 1824), artículo 13. También la Constitución Mexicana de 4 de octubre de 1824, en el artículo 50, donde fija las facultades exclusivas del Congreso General, en el apartado 11, incorpora la misma competencia: "Arreglar el comercio con las naciones extranjeras, y entre los diferentes estados de la federación y tribus de los indios".

${ }^{8}$ Constitución de la Provincia de Popayán (17 de julio de 1814), artículo 17.

${ }^{9}$ Acta de la Federación de las Provincias Unidas de Nueva Granada (27 de noviembre de 1811), artículo 23. 
de indios bárbaros que se hallen situadas o establecidas dentro de dichos territorios; antes bien se las respetará como legitimos y antiguos propietarios, proporcionándoles el beneficio de la civilización y religión por medio del comercio y por todas aquellas vías suaves que aconseja la razón y dicta la caridad cristiana, y que sólo son propias de un pueblo civilizado y culto; a menos que sus hostilidades nos obliguen a otra cosa" ${ }^{10}$. Se les reconoce como pueblos extranjeros, fronterizos, errantes, con los que se puede "entrar en tratados y negociaciones", pero nunca se les considera como Estados y se les trata siempre desde una posición de superioridad: "protegiendo sus derechos con toda humanidad y filosofía que demanda su actual imbecilidad, y la consideración de los males que ya les causó, sin culpa nuestra, una nación conquistadora" ${ }^{11}$. No se pretende su conquista, pero tampoco se les admite como miembros de la misma comunidad. La advertencia final (" a menos que sus hostilidades nos obliguen a otra cosa”) tampoco debe echarse en saco roto. Son considerados como extraños, como potenciales enemigos, una amenaza latente.

\section{Politica paternalista.}

En las constituciones de que estamos tratando encontramos otra política respecto a los indios que podemos denominar paternalista. Se establece una política de protección, en la que el indígena es considerado un menor de edad, aunque lo sea temporalmente, y se pretenda a largo plazo su integración, pero no se busca activamente con medidas concretas. El indio es considerado un menor, alguien que precisa tutela y cuidado. Es una concepción conservadora que, en cierto modo, continúa la política paternalista propia de la época colonial.

El licenciado Juan de Matienzo justificaba la política española en América diciendo que "estos indios son como menores o incapaces, y como a tales les damos curador para pleitos y para hacer cualesquier contratos, y la mesma Audiencia es su curadora e protetora"12. Los indios eran considerados jurídicamente como "pobres", "miserables", que podían por ello pleitear gratis. La encarnación más evidente de la actitud paternalista fue la creación de la figura del Protector de naturales. Es cierto que las nuevas constituciones emancipadoras protestan contra la época colonial y exigen una mayor consideración y respeto para la población indígena, pero el planteamiento básico de alguna de ellas sigue siendo paternalista: "Pero, si dentro de los límites conocidos de las provincias, o entre provincia y provincia, hubiera naciones de esta clase, ya establecidas que hoy pudieran hacer cómodamente parte de esta unión o de las mismas provincias, principalmente cuando ya no las aterra un tributo ignominioso, ni un gobierno bárbaro y despótico, como el que ha oprimido a sus hermanos, por trescientos años, se las convidará y se las atraerá por los medios más suaves, cuales son regularmente los del trato y el comercio, a asociarse con nosotros, y sin

\footnotetext{
${ }^{10}$ Ibíd., artículo 24.

${ }^{11}$ Ibíd., artículo 25.

${ }^{12}$ Matienzo, Juan, Gobierno del Perú con todas las cosas pertenecientes a él y a su historia, parte $1^{\mathrm{a}}$, cap. $13^{\circ}$ (1567, reimpresión París/Lima, 1967), p. 26.
} 
que sea un obstáculo su religión, que algún día cederá tal vez el lugar a la verdadera, convencidos con las luces de la razón y el evangelio que hoy no pueden tener"13.

Se sigue pensando en los indios como necesitados de protección y se muestra la conveniencia de convertirlos tanto a la fe como a la civilización. Esta actitud constitucional hacia los indios, pese a las protestas formales contra la época colonial, continuaba la política seguida oficialmente por la metrópoli durante ese período. Las "Leyes de Indias" están llenas de referencias a la necesidad del buen trato y a la conversión pacífica de los indios, hechas siempre desde la convicción más firme de la superioridad de la propia cultura. Los indios debían ser civilizados, o sea, debían incorporarse a la cultura española. En la Constitución chilena de 1822 se establecen entre las competencias del Congreso la de "cuidar de la civilización de los indios del territorio" 14 . No hay un corte profundo con el pretendido paternalismo anterior, centrado en la predicación del Evangelio, aunque se recalca más la importancia del comercio y la suavidad de las formas, ya que los indios siguen siendo considerados como bárbaros, carentes de cultura, a los que hay que civilizar, si bien de manera pacífica. La importancia del comercio como vía civilizadora y pacificadora es, sin duda, un eco de las conocidas afirmaciones de Montesquieu cuyas obras eran bien conocidas de los constituyentes americanos ${ }^{15}$.

A medio camino de la actitud paternalista y la descalificación se halla la Constitución de Ecuador de 1830, que dice: "Este Congreso constituyente nombra a los venerables curas párrocos por tutores y padres naturales de los indios, excitando su ministerio de caridad a favor de esta clase inocente, abyecta y miserable" ${ }^{16}$. No hay un corte profundo con los antiguos Protectores de Indios que nombraban los monarcas españoles. Por el lenguaje utilizado se aprecia que se sigue considerando a los indios como inferiores y no como iguales.

\section{Politica de igualdad.}

Un tercer grupo de las constituciones hispanoamericanas de esta época trasladan a sus textos un planteamiento de rigurosa igualdad con respecto a los indios. Presentan al indígena como un ciudadano más. Podemos considerar que se trata de las constituciones más influidas por las francesas, especialmente las de 1793 y 1795. Se les va a reconocer a los indios no sólo derechos civiles y económicos, sino también derechos políticos. Esta actitud era coherente con las reclamaciones presentadas por los diputados americanos ante las Cortes de Cádiz para que se incluyera a la población indígena y africana en los cómputos para calcular la representación americana ${ }^{17}$.

\footnotetext{
${ }^{13}$ Acta de la Federación de las Provincias Unidas de Nueva Granada (1811), artículo 26.

${ }^{14}$ Constitución de Chile (30 de octubre de 1822), artículo 47, apartado 6.

${ }^{15}$ Véase: Montesquieu, Ch., De lesprit des lois, lib. XX, cap. $1^{\circ}$ (1748, París, 1878), p. 297.

${ }^{16}$ Constitución Política de la República de Ecuador (23 de septiembre de 1830), tít. VIII, artículo 68. Consultada en http://pdba.georgetown.edu/Constitutions/Ecuador/ecuador30. html (julio de 2012).

${ }^{17}$ Cuando el primero de agosto de 1811 los diputados americanos presentan un escrito a las Cortes de Cádiz, examinando las causas del malestar en América, se quejan sobre todo de la escasa representación que se les había concedido. La Junta Central había declarado la igual-
} 
La Constitución de la República de Tunja de 1811 es una de las más igualitarias en lo que se refiere a los indios. En su "Preámbulo" recuerda "las ningunas ventajas que esta provincia ha reportado en permanecer bajo el sistema de gobierno de Espa$\tilde{n} a$, en el espacio de trescientos años" ${ }^{\prime 1}$. Republicanamente se insiste en que nadie nace "rey, magistrado, legislador o juez" y en la igualdad de todo hombre ante la ley, sin más diferencia que aquella "que se derive de la consideración que le den sus virtudes" ${ }^{19}$. Esta Constitución de Tunja afirma la soberanía popular, la libertad de las elecciones, la igualdad de los reyes con los demás hombres ${ }^{20}$, la "execración que merece un tirano" ${ }^{21}$ y considera a la ley como "expresión de la voluntad general"22. Asienta como uno de sus principios básicos la igualdad de derechos naturales y no se desmiente a sí misma, como a veces suele suceder, en el resto del articulado: "Dios ha concedido igualmente a todos los hombres ciertos derechos naturales, esenciales e imprescriptibles, como son: defender y conservar su vida, adquirir, gozar y proteger sus propiedades, buscar y obtener su seguridad y felicidad"23. En esta misma afirmación igualitaria hay que destacar la exigencia de iguales tributos para todos: "Ningún hombre, ninguna clase, corporación o asociación de hombres puede ni debe ser más gravada por la ley que el resto de la comunidad"24. De manera reveladora exige la misma instrucción "a todas las clases de los ciudadanos" 25 , mencionando de manera explícita a los indios: "Ni en las escuelas de los pueblos, ni en las de la capital habrá preferencias ni distinciones entre blancos, indios, $u$ otra clase de gente" 26 . Conforme a la ideología ilustrada se insiste en que las únicas diferencias a considerar serán aquellas que se basen en el talento y el esfuerzo.

Igualitaria es también la Constitución de Cundinamarca de 1812, ya que de manera explícita se reconocen derechos políticos a los indios: "Los indios gozan de todos los derechos de ciudadanos y tienen voz y voto en todas las elecciones, como los demás de esta república" ${ }^{27}$. Sorprende también que en su prelación de valores fundamentales, a imitación de la Constitución francesa de 1793, se mencione en primer lugar la igualdad y no la libertad como suele ser lo usual ${ }^{28}$.

A este mismo grupo habría pertenecido el Proyecto de Constitución para la Provincia de Salta, redactado entre 1821 y 1825, cuyo artículo 35 señala: "Los

dad de representación de ambos hemisferios, pero lo cierto es que los diputados de América convocados a las Cortes fueron muchos menos. Véase: KING, James, The Colored Castes and American Representation in the Cortes of Cádiz, en Hispanic American Historical Review, 33 (1953), pp. 33-64.

${ }^{18}$ Constitución de la República de Tunja (23 de diciembre de 1811), "Preámbulo".

${ }^{19}$ Ibíd., sección preliminar, cap. $1^{\circ}$, artículo 4 .

${ }^{20}$ Ibíd., sección preliminar, cap. $1^{\circ}$, artículo 27 .

${ }^{21}$ Ibíd., sección primera, cap. $2^{\circ}$, artículo 21.

${ }^{22}$ Ibíd., sección primera, cap. $3^{\circ}$, artículo 5 .

${ }^{23}$ Ibíd., cap. $1^{\circ}$, artículo 1 .

${ }^{24}$ Ibíd., cap. $1^{\circ}$, artículo 5 .

${ }^{25}$ Ibíd., cap. $1^{\circ}$, artículo 17.

${ }^{26}$ Ibíd., sección $6^{\mathrm{a}}$, artículo 3 .

${ }^{27}$ Constitución de Cundinamarca (18 de julio de 1812), "Declaración de derechos y deberes", artículo 24 .

${ }^{28}$ Ibíd., artículo 1. Este mismo orden (igualdad, libertad, seguridad y propiedad) está en el artículo segundo de la Constitución francesa de 1793. 
indios; $y$ demás gentes de color de la provincia son iguales en dignidad y en derechos a todos los demás ciudadanos, gozarán de las mismas preminencias, serán regidos por las mismas leies" ${ }^{29}$. Sus numerosas referencias al pacto social y a los derechos de los ciudadanos dejan clara la influencia de las constituciones francesas.

\section{Política de asimilación.}

En este cuarto bloque de constituciones el indígena es considerado como un sujeto jurídico, un titular de derechos civiles más que políticos, un futuro propietario. Supone una política asimilacionista, propia de la ideología liberal que trata de ampliar el mercado no sólo de mercancías, sino de mano de obra. Se suprimirán los trabajos coactivos, involuntarios, característicos de la época colonial, para que los indígenas puedan vender libremente su fuerza de trabajo.

La que podemos llamar tesis integracionista fue la seguida por la mayoría de las constituciones hispanoamericanas. Durante la colonia los indios habían sido intencionadamente mantenidos aparte, incluso aunque fuera por supuestos motivos de protección, pero lo cierto es que quedaron aislados en "repúblicas de indios" con leyes, gravámenes y trabajos diferentes de los españoles. La mayor parte de las constituciones emancipadoras hispanoamericanas buscarán la integración rápida de los indios junto con el resto de la población. Los indígenas son jurídicamente reconocidos como titulares de derechos. Se declara que los indios deben ser iguales al resto de ciudadanos, pero, como de hecho no lo son, se adoptan múltiples medidas para lograr su plena equiparación.

La Constitución de Socorro de 1810 es un buen ejemplo de este planteamiento. Se rechaza la política de minoría de edad mantenida durante la colonia, se decreta la igualdad impositiva suprimiendo el tributo propio de los indios, se reparten las tierras comunales y se busca la integración de los indios con el resto de la sociedad; sin embargo, la plena representación política de los indios queda condicionada a su integración efectiva: "Asimismo se declara que desde hoy mismo entran los indios en sociedad con los demás ciudadanos de la Provincia a gozar de igual libertad y demás bienes que proporciona la nueva Constitución, a excepción del derecho de representación que no obtendrán hasta que hayan adquirido las luces necesarias para hacerlo personalmente" 30 .

La Constitución Federal de Venezuela de 1811 hace explícito su propósito de ruptura respecto a la política de tutela mantenida durante la colonia. Se impone una inclusión que debe pasar por la inculturación y la división de la propiedad comunal. La consideración de nacionales de los nuevos Estados precisará el abandono de su propia cultura ancestral. Serían ciudadanos plenos cuando fueran debidamente incorporados a la religión católica y a la cultura occidental. En la Constitución Federal de Venezuela de 1811 se afirma de manera rotunda la igualdad de todos los ciudadanos, igualdad ante la ley e igualdad de razas, que se apoya en la supresión de algunas de las discriminaciones más odiosas llevadas a

${ }^{29}$ San Martino de Dromi, Ma Laura (editora), Documentos constitucionales argentinos (Buenos Aires, 1994), p. 1.110.

${ }^{30}$ Acta de la Constitución del Estado Libre e Independiente del Socorro (15 de agosto de 1810). 
cabo contra los indios, como fueron los impuestos especiales y los trabajos personales forzosos. Por eso, cuando se refiere a los ciudadanos "que hasta hoy se han denominado Indios" denuncia la falta de aplicación de las leyes de la Monarquía Española que se ocupaban de ellos y vuelca todo su esfuerzo en "conseguir la ilustración de todos los habitantes del Estado, proporcionarles escuelas, academias y colegios en donde aprendan todos los que quieran los principios de Religión, de la sana moral, de la politica, de las ciencias y artes útiles y necesarias para el sostenimiento y prosperidad de los pueblos, procuren por todos los medios posibles atraer a los referidos ciudadanos naturales a estas casas de ilustración y enseñanza, hacerles comprender la intima unión que tiene con todos los demás ciudadanos, las consideraciones que como aquellos merecen del Gobierno y los derechos de que gozan por el solo hecho de ser hombres iguales a todos los de su especie" 31 .

\section{LAS MEDIDAS PARA LA INTEGRACIÓN DE LA POBLACIÓN INDÍGENA}

La política de integración de los indios se articulará en torno a tres medidas principales, a saber, la instrucción, la supresión de los tributos personales y la división de la propiedad comunal.

En la Constitución de Mariquita de 1815 encontramos un planteamiento de este tipo. De un lado, se pretende romper con el paternalismo de la colonia al que se denuncia por su falta de efectividad, ya que la población indígena "no ha conseguido el fruto apreciable de algunas leyes que la monarquía española dictó a su favor, porque los encargados del Gobierno en estos paises tenian olvidada su ejecución" 32 . Pero también se critican los efectos perversos que dicho paternalismo trae consigo, por lo que se estatuye la nulidad de las "Leyes de Indias", así como de "ciertos tribunales protectores y privilegios de menor edad a dichos naturales, las cuales, dirigiéndose al parecer a protegerlos, les han perjudicado sobremanera, según lo ha acreditado la experiencia" 33 . Por ello, lo que se pretende es una política de integración pacífica de los indios, dando señalada importancia a su instrucción: "a fin de conseguir por este medio sacarlos del abatimiento y rusticidad en que los ha mantenido el antiguo estado de las cosas, y que no permanezcan por más tiempo aislados y aun temerosos de tratar a los demás hombres" 34 .

El modelo liberal, continuador de las tesis ilustradas y racionalistas, que está detrás de esta concepción, pretendía una asimilación rápida y total de los indios. Se quiere que sean iguales al resto de la población y se confía en el todopoderoso medio de la instrucción y la enseñanza para conseguirlo. La confianza en la educación, como en el progreso que ésta hace posible, es algo consustancial a este pensamiento. La Ilustración tenía una confianza desbordante en el poder de la cultura y de la educación. Con respecto a los indios se confía en que poco a poco irían desapareciendo las diferencias por la fuerza expansiva de la razón. Los indios

\footnotetext{
${ }^{31}$ Constitución Federal de Venezuela (21 de diciembre de 1811), artículo 200.

${ }^{32}$ Constitución o forma de gobierno acordada por los delegados del Estado de Mariquita (Colombia) (4 de agosto de 1815), tít. 23ㅜ, artículo 1.

${ }^{33}$ Ibíd., tít. $23^{\circ}$, artículo 2.

${ }^{34}$ Ibíd., tít. $23^{\circ}$, artículo 1 .
} 
necesitaban ser ilustrados, como los demás seres humanos, pero por ilustración se entendía la asimilación a la cultura nacional. Paradójicamente, las constituciones posteriores, al insistir en este requisito de la ilustración para el ejercicio de los derechos políticos, acabarán favoreciendo una mayor exclusión.

En Centroamérica, José Cecilio del Valle (1777-1834) todavía muestra este pensamiento ilustrado. Es un sabio que trata de conocer y de asimilar pacíficamente a los indios, que confía en la hibridación y en el mestizaje. La Constitución de Perú de 1828, al fijar las competencias de las Juntas Departamentales, dice que éstas deben "entender en la reducción y civilización de las tribus de indígenas limitrofes al departamento y atraerlos a nuestra sociedad por medios pacificos" 35 . Es un claro intento de integración aunque por medios pacíficos.

Igualmente reveladora es la propuesta, incluida en el proyecto de Constitución argentina de 1813, de proporcionar a los indios "educación bastante a ponerlos al nivel de las demás clases civilizadas, entre tanto tomará las medidas más prudentes a establecer el buen orden y policía en sus poblaciones, la emulación en el trabajo e industria" 36 .

La mentalidad ilustrada que inspira estas constituciones rechaza la existencia de leyes específicas para la población indígena que, por buenas que fueran en sus pretensiones, se insiste en ello, nunca se han cumplido. El Proyecto de Constitución de 1813 de Argentina establece que los indios "son iguales en derechos y en dignidad" al resto de los demás ciudadanos, y pretende que sean regidos por las mismas leyes, reprochando a la política colonial anterior que "so pretexto de protección" dejaba a "estos primitivos Americanos en un eterno y degradante pupilaje" ${ }^{37}$. Explícitamente se condena el régimen de servidumbre que se había establecido durante la colonia. Se quiere integrar a los indios y hasta parece que se confía en que ese nombre desaparezca en el futuro ("que hasta hoy se han denominado Indios" ${ }^{38}$ ). Estamos ante un abandono explícito de la política paternalista de la colonia, a la que se considera totalmente equivocada.

Algunos pensadores que influyeron en el logro de la emancipación americana, ya habían defendido antes de la independencia posiciones de estricta igualdad y criticado la política paternalista respecto de los indios. Por ejemplo, Antonio Nariño (1765-1823), conocido como el Precursor, e importante protagonista de la independencia de Colombia, defiende un planteamiento de total equiparación: "Sería de desear que esta raza miserable de hombres saliera del estado en que se halla en el dia. A pesar de los privilegios y especial protección que les acuerdan nuestras leyes, los que los estamos viendo palpamos su miseria. Yo creo que reduciendo los indios a la clase de los demás vasallos, el Estado ganaría y haria una acción muy conforme a las piadosas máximas de nuestro Gobierno y a sus intereses"39. La denominación de "miserables" había sido el término jurídico de la legislación indiana que impli-

\footnotetext{
${ }^{35}$ Constitución de Perú (18 de marzo de 1828), artículo 75, apartado $10^{\circ}$.

${ }^{36}$ Proyecto de Constitución de Argentina (1813), artículo 177.

${ }^{37}$ Ibíd.

${ }^{38}$ Constitución Federal de Venezuela (21 de diciembre de 1811), artículo 200.

${ }^{39}$ Citamos por Gómez Hoyos, Rafael, La revolución granadina de 1810. Ideario de una generación y de una época (1781-1821) (Bogotá, 1962), I, p. 241.
} 
caba la consideración de los indios como menores de edad, necesitados de una permanente tutela, de ahí que se nombraran los protectores de indios para su representación y defensa ante los tribunales.

La política de integración, defendida por Nariño y adoptada luego por constituciones de clara influencia liberal, tiene como una medida inmediata para llevar a cabo la asimilación indígena la prohibición de los tributos especiales, exclusivos de los indios, y de manera muy particular los que conllevaban algún tipo de trabajo personal. Así lo hace la Constitución del Estado colombiano de Mariquita: "prohibiendo desde ahora que puedan aplicarse involuntariamente a prestar sus servicios a los tenientes o curas de sus parroquias ni otra persona alguna" 40 .

El sometimiento de los indios a las mismas leyes que el resto de la ciudadanía encontró una concreción fundamental cuando se suprimieron los impuestos personales que les gravaban, entre ellos, la conocida como mita, que permitía la utilización de la mano de obra indígena para la extracción de metales preciosos. El debate mantenido en la última época de la colonia en contra del gravamen personal sobre los indios explica que su supresión formara parte del ideario independentista desde los primeros momentos.

La Constitución Federal de Venezuela de 1811 nos muestra cómo muchos de esos trabajos forzados beneficiaban al estamento eclesiástico: "A fin de conseguir por este medio sacarlos del abatimiento y rusticidad en que los ha mantenido el antiguo estado de cosas y que no permanezcan por más tiempo aislados y aun temerosos de tratar a los demás hombres, prohibiendo desde ahora que puedan aplicarse involuntariamente a prestar sus servicios a Tenientes o Curas de sus parroquias, de a otra persona alguna" 41 .

Sin abandonar la pretensión básica de asimilar a los indios y convertirlos en sujetos de derechos iguales al resto, encontramos alguna constitución que no deja de reconocer que, dada la situación de desigualdad existente, hay que adoptar medidas especiales para ellos. En el territorio de la actual Argentina, la Constitución de las Provincias Unidas en Sudamérica de 1819 exige igualdad, las mismas leyes para todos y, precisamente por eso, impone la extinción de la tasa que recaía sobre los indios y que suponía una evidente discriminación, pero también propone lo que ahora llamaríamos "medidas positivas" para compensar la desigualdad de hecho existente: "Siendo los indios iguales en dignidady en derecho a los demás ciudadanos, gozarán de las mismas preeminencias y serán regidos por las mismas leyes. Queda extinguida toda tasa o servicio personal bajo cualquier pretexto o denominación que sea. El Cuerpo Legislativo promoverá eficazmente el bien de los naturales por medio de leyes que mejoren su condición hasta ponerlos al nivel de las demás clases del Estado" "42.

No hay ninguna referencia expresa a los indios en la Primera Constitución de Guatemala de 1825, pero la insistencia en la igualdad contributiva puede entender-

${ }^{40}$ Constitución o forma de gobierno acordada por los delegados del Estado de Mariquita (1815), tít. $23^{\circ}$, artículo 1 .

${ }^{41}$ Constitución Federal de Venezuela (1811), artículo 200.

${ }^{42}$ Constitución de las Provincias Unidas en Sudamérica (22 de abril de 1819), artículo cxxviii. 
se como la supresión de los tributos propios de los indios: "Las contribuciones serán repartidas igualmente entre los habitantes del Estado, con proporción a sus facultades, sin privilegio ni excepción alguna" ${ }^{3}$. La supresión de los tributos especiales era un punto de acuerdo de ideologías diversas; tanto de las liberales, que denunciaban los restos feudales del Antiguo Régimen; como de las republicanas, que exigían la igualdad de las leyes para todos los ciudadanos.

Frente a la práctica colonial de la estratificación social por razas, se defiende una política de mayor integración. El racionalismo rechaza toda clase de grupos, también los de raíz étnica, y defiende la mayor igualdad posible. Ante la doctrina colonial, que se basaba en establecer multitud de diferencias, raciales, corporativas, gremiales, las nuevas constituciones tienen como política oficial el establecimiento de una ciudadanía en principio única, donde no haya distinciones nobiliarias ni estamentales y donde el único tratamiento permitido sea el común de "ciudadano".

La pretensión de acabar con las discriminaciones raciales en las leyes tenía también importantes precedentes. La igualdad de las distintas razas ya había sido propugnada por los artífices de la llamada "Conspiración de Gual y España”, que tiene lugar en Caracas en 1797. En las ordenanzas elaboradas para planificar dicho levantamiento se incluye la siguiente tesis: "Se declara la igualdad natural entre todos los habitantes de las Provincias y distritos y se encarga que entre blancos, indios, pardos y morenos, reine la mayor armonía, mirándose como hermanos en Jesucristo iguales por Dios, procurando aventajarse sólo unos y otros en méritos y virtud que son las dos unicas distinciones reales y verdaderas que hay de hombre a hombre y habrá en lo sucesivo entre todos los individuos de nuestra república" ${ }^{44}$. Aunque se apela aquí al cristianismo para reforzar la tesis igualitaria, estas ordenanzas, al igual que otros escritos de estos mismos autores, reflejan con claridad la influencia de la Revolución francesa, y, sobre todo, de la declaración de derechos incluida en la Constitución francesa de 1793.

Los indios habían sido excluidos del ejército y de las milicias e incluso se les prohibía el uso de las armas consideradas como peligrosas. Las nuevas constituciones hispanoamericanas acabarán con esa política de discriminación y harán de la incorporación en el ejército un instrumento de asimilación de la población indígena. La Constitución de las Provincias Unidas del Centro de América de 1824 reconoce lo que podríamos llamar el derecho republicano a llevar armas que encontramos en las Enmiendas Americanas ${ }^{45}$.

Conforme avanza el siglo XIX y se constata el fracaso de la integración pacífica,

${ }^{43}$ Primera Constitución de Guatemala (11 de octubre de 1825), tít. 11º, artículo 228.

${ }^{44}$ Grases, Pedro, La conspiración de Gual y España y el ideario de la independencia (Buenos Aires, 1949), pp. 175-176. Se corresponde con la tesis 32a de las Ordenanzas elaboradas para esa conspiración.

${ }^{45}$ El artículo 176, apartado primero, de la Constitución de las Provincias Unidas del Centro de América, de 22 de noviembre de 1824, que era la Constitución Federal de los Estados de Costa Rica, Nicaragua, Honduras, El Salvador y Guatemala, establece que no se puede, salvo situaciones excepcionales de tumulto o rebelión, "desarmar a ninguna población, ni despojar a persona alguna de cualquier clase de armas que tengan en su casa o de la que lleve lícitamente”. 
se empiezan a defender otras políticas más intransigentes con los indios, que quieren una asimilación rápida y no dudan en acudir, si es preciso, al uso de la fuerza. Un defensor de esta política de integración rápida, en Centroamérica, es Antonio Batres Jáuregui (1847-1928) ${ }^{46}$. Se permite por ejemplo la incorporación coactiva de los indios en el ejército, como un instrumento eficaz de aculturación. Esta será una de las principales vías de desarraigo de los indígenas. Estas propuestas políticas se verán respaldas por doctrinas positivistas y evolucionistas que van a justificar incluso planteamientos racistas. Unos indios serán declarados como civilizables, y otros radicalmente excluidos como "salvajes". La teoría del progreso de la Ilustración es sustituida por unas tesis antropológicas mucho más pesimistas.

Una queja permanente de los criollos y, al final, un motivo más para la independencia, había sido la escasa representación concedida al hemisferio americano tanto para la formación de la Junta Central como para las Cortes de Cádiz. Así y todo, la elección de estos representantes recayó sobre los cabildos de las principales ciudades que vieron reforzada su capacidad de controlar el territorio adyacente. En el pliego de instrucciones para su diputado, el cabildo de Santafé de Bogotá, entre otras reclamaciones y quejas contra los funcionarios enviados desde la Península, se refiere a "las extorsiones que sufre el indio, condenado a una eterna esclavitud, y a un ignominioso tributo que le impuso la injusticia y la sinrazón" ${ }^{4}$. Pero entre las peticiones de los cabildos llevadas a la Península hay otras que perjudican claramente a la población indígena, de manera señalada la libertad de comprar y vender los resguardos ocupados por los indígenas. "Estas reivindicaciones, aunque se sustentaban en discursos compasivos en contra de la explotación de los indios, en la práctica ponían en peligro la supervivencia de esta etnia, al arrebatarle sus tierras comunales, su forma de vida comunitaria y convertirlos, según el deseo de los criollos, en 'ciudadanos libres'" 48 . Los criollos muestran en estas instrucciones los mismos prejuicios que los españoles peninsulares tuvieron respecto a la población indígena, les creen incapaces de actuar por sí mismos y se consideran sus representantes naturales. La medida integracionista de mayor calado, y la que más afectará a las poblaciones indígenas, fue la pretensión de acabar con las propiedades comunales que habían disfrutado las comunidades indígenas de manera tradicional y que las autoridades coloniales habían respetado.

En la Constitución de Socorro de 1810, después de declarar a los indios "libres del tributo que hasta ahora han pagado", se va a mandar "que las tierras llamadas resguardos se les distribuyan por derecho de sucesión; pero que no puedan enajenarlas

\footnotetext{
${ }^{46}$ Véase: García GiRÁldez, Teresa, El pensamiento político liberal centroamericano del siglo XIX: José Cecilio del Valle y Antonio Batres Jáuregui, en Revista Complutense de Historia de América, 35 (2009), pp. 23-45.

${ }^{47}$ Torres Tenorio, Camilo, Representación del Cabildo de Santa Fe a la Junta Central de España (20 de noviembre de 1809) (Bogotá, 1960), pp. 18-19.

${ }^{48}$ REYEs, Catalina, La ambigüedad entre lo antiguo y lo nuevo. Dos mundos que se entrecruzan: Nueva Granada, 1808-1810, en CHust, Manuel (coordinador), Doceañismos, constituciones e independencias. La Constitución de 1812 y América (Madrid, 2006), p. 110.
} 
por venta o donación hasta que hayan pasado veinticinco años contado desde el día en que cada uno se encargue de la posesión de la tierra que le corresponda" ${ }^{\prime}$.

De una parte, se aplica la concepción liberal de la propiedad que exigía la distribución de los bienes comunes y la eliminación de los regímenes especiales, pero, a la vez, de manera incoherente, se establece una grave limitación, la de imposibilitar su venta durante un prolongado período de tiempo, hay que suponer que para evitar que los indios fueran engañados en la venta. Esta medida integracionista de acabar con la propiedad comunitaria indígena de la tierra, forzando la división de las propiedades comunes, aparece recogida en la mayoría de las constituciones hispanoamericanas del periodo que estamos considerando. La Constitución Federal de Venezuela de 1811 señala respecto a la propiedad de los indios lo siguiente: " $y$ permitiéndoles el reparto en propiedad de las tierras que les estaban concedidas y de que están en posesión, para que a proporción entre los padres de familia de cada pueblo, las dividan y dispongan de ellas como verdaderos señores, según los términos y reglamentos que formen los Gobiernos provinciales" ${ }^{50}$. Debe quedar claro que, aunque el texto hable de "permitir" y parezca que se les está concediendo un nuevo derecho, la distribución de la propiedad indígena lo que realmente presupone es que las comunidades indígenas no eran verdaderas propietarias de sus tierras, por inmemorial que fuera su posesión de buena fe, lo que de paso contradecía la propia legislación liberal.

El proyecto de Constitución argentina de 1813 establece el reparto de la propiedad comunal que tenían los indios. Según este proyecto, las tierras de sus mayores, "de las que tienen un precario y oneroso usufructo" deberán ser repartidas "en propiedad por suertes proporcionadas a los Padres de familia de las respectivas comunidades sin más condición que la de cultivarlas" ${ }^{51}$.

La Constitución colombiana del Estado de Mariquita consagra con respecto a las propiedades de los indios: "el reparto en propiedad de las tierras que les estaban concedidas y de que están en posesión, para que a proporción entre los padres de familia de cada pueblo las dividan y dispongan de ellas como verdaderos señores" 52 . Se estatuye una distribución de las propiedades negando los derechos de propiedad colectivos y comunales.

En el Reglamento Provisional Politico del Imperio Mexicano de 1822, al hablar de las competencias de las Diputaciones Provinciales, se establece que no omitirán diligencia para que "pueda hacerse efectivo en plena propiedad, entre los ciudadanos indígenas y entre los beneméritos, industriosos, el repartimiento de tierras comunes $o$ realengas, salvo los ejidos precisos a cada población" 53 . La idea de que el retraso económico estaba relacionado con una falta de aprovechamiento de la tierra es común

\footnotetext{
${ }^{49}$ Acta de la Constitución del Estado libre e independiente del Socorro (15 de agosto de

${ }^{50}$ Constitución Federal de Venezuela (1811), artículo 200.

${ }^{51}$ Proyecto de Constitución de Argentina (27 de enero de 1813), artículo 177.

${ }^{52}$ Constitución o forma de gobierno acordada por los delegados del Estado de Mariquita (Colombia, 1815), tít. XXIII, artículo 1.

${ }^{53}$ Reglamento provisional político del Imperio Mexicano (18 de diciembre de 1822), artículo
} 1810). 90. 
a todo el período y se pretende combatir suprimiendo las formas de propiedad colectiva, así como las diversas formas de mayorazgos y otras vinculaciones.

No hay ninguna referencia concreta a los indios en la Constitución chilena de 1828, pero la manera de insistir en la supresión de toda clase de vinculación de la tierra podría extenderse también a la propiedad comunal de los indígenas: "Quedan abolidos para siempre los mayorazgos, y todas las vinculaciones que impidan el enajenamiento libre de los fundos" 54 . Los preceptos constitucionales dirigidos a dividir la propiedad comunal de los pueblos indios en propiedades privadas responden a la extendida concepción liberal que considera a la propiedad colectiva como ineficiente y ve en la propiedad privada el principal baluarte de la estabilidad social y de la seguridad del Estado. Esta concepción de la propiedad del liberalismo forma parte de la misma ideología que rechaza los mayorazgos, las fundaciones, las vinculaciones y todos los impedimentos jurídicos que dificultaban la transmisión rápida de la propiedad.

En la Constitución del Estado de Socorro, en Colombia, se determina que "una generación no podrá limitar o privar de su libre uso a las generaciones venideras con las vinculaciones, mayorazgos y demás trabas contrarias a la naturaleza, y sagrado derecho de propiedad y a las leyes de la sucesión" 55 . Otro ejemplo de esta exaltación casi religiosa de la propiedad dividida lo encontramos entre Los deberes del ciudadano de la Constitución Provisional de la Provincia de Antioquia de 1815 donde se establece: "Cada uno de los ciudadanos debe respetar y conservar religiosamente las propiedades ajenas, pues en ellas reposa el cultivo de las tierras, la industria, el comercio, las producciones del trabajo y todo el orden social'56.

Estos textos, en los que se asocia la defensa de la propiedad con la conservación del orden social, son representativos de la ideología liberal que acabaría por imponerse a lo largo del siglo XIX. En esta concepción, la propiedad no es uno más de los derechos sino la base de todos ellos, porque las diferentes libertades son entendidas como propiedades de los ciudadanos y, sobre todo, porque gracias al sufragio censitario sólo serán considerados como auténticos ciudadanos los propietarios.

Lograda la independencia de la metrópoli peninsular, el valor constitucionalmente establecido será el de la igualdad de todas las razas, pero lo cierto es que las nuevas constituciones no supusieron sin más la igualdad real de todos los habitantes de los nuevos Estados. Hay importantes capas de población que quedaron de hecho, y en algunos casos de Derecho, excluidas, como fue el caso de la población indígena. El pensamiento liberal llevaba dentro de sí no pocas contradicciones. Por una parte, era heredero directo de la Ilustración y de la Revolución francesa, y trataba de concretar en las constituciones políticas los valores y los derechos reconocidos en la Declaración de derechos del hombre y del ciudadano. Pero el mismo pensamiento que defendía la igualdad y la libertad atribuiría un lugar subordinado a múltiples categorías de seres humanos.

\footnotetext{
${ }^{54}$ Constitución de Chile (8 de agosto de 1828), cap. XII, artículo 126.

${ }^{55}$ Acta de la Constitución del Estado libre e independiente del Socorro (15 de agosto de 1810), Base cuarta.

${ }^{56}$ Constitución Provisional de la Provincia de Antioquia (1815), artículo 9.
} 
En este punto fundamental, las constituciones hispanoamericanas no fueron más allá de la Constitución de Cádiz de 1812, en la que se inspiraron algunas de ellas. Se recoge en esa Constitución el pensamiento liberal que ciertamente acaba con la monarquía absoluta, pero que impone los valores de una sociedad desigual donde no todos los súbditos son ciudadanos. La mejor traducción jurídica de esa contradicción se produce al establecer una profunda distinción entre los españoles y los ciudadanos. Los españoles disfrutarán de derechos civiles, podrán contratar y ser propietarios, pero la verdadera ciudadanía quedará reservada a los ciudadanos, que serán aquellos que dispongan de suficiente renta o recursos económicos como para demostrar su autonomía política. El llamado sufragio censitario y numerosos requisitos adicionales para ocupar los cargos políticos más importantes serán elementos básicos de la organización política que se establece en las primeras constituciones sudamericanas en las que se organizan los nuevos Estados una vez que logran la emancipación de España. Se proclama en esas constituciones una y otra vez el valor de la igualdad pero se entenderá ésta únicamente en sentido jurídico, como la existencia de "una misma ley para todos los ciudadanos" 57 . Se rechazan, en alguna ocasión, las jurisdicciones especiales de carácter eclesiástico, se suprimen en todas los privilegios de la nobleza, pero subsisten las jurisdicciones militares y los altos cargos políticos a menudo se blindan el desempeño de los mismos.

En las constituciones que estamos examinando nos encontramos con prolijas listas de "no ciudadanos" o de ciudadanos "pasivos", o sea, de ciudadanos de segunda categoría, a los que se les priva de derechos políticos. Ahora bien, esa lista de excluidos es claramente incompleta, porque hay otras categorías de personas que quedan excluidas sin ni siquiera mencionar que lo son. Entre aquellos a los que no se priva expresamente, pero sí fácticamente, de los derechos políticos están siempre las mujeres y casi siempre los indios. Sobre las mujeres lo más habitual es no decir absolutamente nada. Sobre los indios, aunque hemos visto que hay algunas menciones expresas, los requisitos de propiedad e ilustración establecidos para la participación política les excluían de manera patente. La mayoría de los pobres, entre los que deben contarse los indios, quedan excluidos de la vida política por el sistema electoral, que impone una doble -a veces triple- elección exigiendo siempre para ser elegido una disposición de capital que resultaba elitista.

Hay en esos textos una reiterada insistencia en que quienes van a ocupar los cargos públicos deben tener "un modo decente de subsistir" 58 . La riqueza condiciona todo el proceso electoral. Para ser ciudadano activo había que tener propiedad. Así en el Proyecto de Constitución Americana de 1798, que se atribuye a Francisco de Miranda, aunque no lleva su firma, se dice que "toda persona que enajenare sus tierras perderá el preciso derecho de ciudadano, y sólo podrá recuperarlo cuando adquiera la cantidad de tierras necesarias al efecto" 59 . Pero recuérdese que la propiedad comunal de los indios era considerada como mero usufructo, de ahí el permanente interés en dividir esas tierras en propiedades particulares. Todas estas

${ }^{57}$ Constitución Federal de Venezuela (1811), artículo 154.

${ }^{58}$ Constitución Provisional de la Provincia de Antioquia (1815), tít. III, artículo 3.

${ }^{59}$ Grases, Pedro (compilador), Pensamiento político de la emancipación venezolana (Caracas, 1988), p. 51. 
constituciones tienen un sistema de sufragio censitario, escalonando la cantidad exigida para ser elector, elegible, o para ser representante, senador e incluso presidente de la República.

En la Constitución de Antioquia de 1812 se excluye a los pobres del derecho a elegir y ser elegidos al reservar este derecho a quien "viva de sus rentas u ocupación, sin pedir limosna, ni depender de otro" 60 . La Constitución de Cundinamarca de 1812 requiere para ser senador, entre otros requisitos, "tener un manejo, renta o provento equivalente al capital de diez mil pesos" ${ }^{61}$. ¿Algún indio podía estar en esa favorable situación económica?

La Constitución de Venezuela de 1830 precisa para ser elector "ser propietario de una propiedad raíz, cuya renta anual sea de doscientos pesos" o tener profesión, oficio o industria útil "que produzca trescientos pesos anuales"62.

Cuando se establece un sistema sucesivo de elecciones, en el que los apoderados elegidos en las primeras elecciones son los únicos encargados de elegir entre ellos a los sucesivos representantes, es frecuente reforzar las cualidades económicas que han de tener quienes pueden ser elegidos como apoderados. La exclusión de los pobres de la ciudadanía se produce de varias maneras. No sólo requiriendo una propiedad o una renta alta para ser elector o elegible, sino suspendiendo el ejercicio de la ciudadanía de los sirvientes domésticos, de los deudores y quebrados, o de los considerados como vagos. Por ejemplo, la Constitución de la República de Colombia de 1830 impone para gozar de los derechos de ciudadano "tener una propiedad raíz cuyo valor libre alcance a trescientos pesos", o ejercer una profesión o industria pero "sin sujeción a otro, en calidad de sirviente doméstico o jornalero"63. La servidumbre era una de las pocas opciones laborales para la población indígena.

Las "leyes de vagos" que vuelven a aparecer en el siglo XIX se convertirán en un instrumento eficaz de presión contra la población indígena, permitiendo otra vez el trabajo personal coactivo.

Otro requisito que limitó de manera señalada la participación política de los indígenas fue la exigencia de saber leer y escribir, frecuente en estas constituciones, como la ecuatoriana de 1830 que lo incluye entre los requisitos para el goce de derechos de ciudadanía ${ }^{64}$. También es cierto que normalmente posponen este requisito durante un cierto plazo. Más interesante para nosotros es la Constitución de Perú de 1828 que, al establecer las condiciones para ser elector parroquial, incluye, además de la ciudadanía, vecindad y cierta propiedad, la de "saber leer y escribir", pero excluye de este requisito "por ahora" a los indígenas remitiendo la solución definitiva a lo que prevenga la ley de elecciones ${ }^{65}$.

Mal general de todas estas constituciones es su deficiente constitucionalidad, ya que se deja la delimitación precisa de los derechos fundamentales a la legislación ordinaria, esto es, a normas carentes de la suficiente protección y estabilidad.

\footnotetext{
${ }^{60}$ Constitución de Antioquia (1812), sección segunda, tít. III, artículo 7.

${ }^{61}$ Constitución de Cundinamarca (18 de julio de 1812), tít. IV, artículo 75.

${ }^{62}$ Constitución de Venezuela (1830), artículo 27.

${ }^{63}$ Constitución de la República de Colombia (5 de mayo de 1830), artículo 14, apartado 4.

${ }^{64}$ Constitución de Ecuador (23 de septiembre de 1830), tít. I, artículo 12, apartado 3.

${ }^{65}$ Constitución de Perú (18 de marzo de 1828), artículo 13, apartado 4.
} 
"Ello no obstante, las mejores declaraciones constitucionales resultarían pronto desvirtuadas por leyes regulatorias de los comicios, más restrictivas, o extendidas prácticas de fraude y compra de votos"66. Si ya aparecen desigualdades recogidas en las constituciones, nunca hay que olvidar que la situación real era mucho peor, ya que en buena medida esas normas constitucionales fueron aplicadas por otras mucho más restrictivas y discriminatorias.

La exigencia de ilustración y suficiencia económica para la participación política formaba parte de los prejuicios políticos compartidos en la época. A modo de ejemplo nos podemos referir a Fray Melchor de Talamantes (1765-1809), mercedario peruano y firme defensor de la independencia mexicana, quien en su Representación Nacional de las colonias. Discurso filosófico (1808) justifica la exclusión de la ciudadanía de todos aquellos que carecen de la instrucción suficiente para decidir por sí mismos, lo que dejaba fuera de la misma a la práctica totalidad de los indígenas, tanto por falta de ilustración como por su pobreza: "El pueblo infimo, en ninguna nación verdaderamente culta goza de este derecho de ciudadano; porque su rusticidad, ignorancia, grosería, indigencia y la dependencia necesaria en que se halla respecto de los hombres ilustrados y poderosos, lo hacen indigno de tan excelente cualidad, que exige una libertad verdadera, incompatible con la ignorancia y la mendicidad' ${ }^{67}$. Tanto el requisito económico como el de ilustración están configurados de manera general por lo que, aunque afectan a la práctica totalidad de la población indígena, excluían también de la ciudadanía a cualesquiera otras personas que carecieran de esos recursos económicos o de la instrucción exigida, pero todavía hay algunos requisitos, muy minoritarios, que iban de manera directa dirigidos a la exclusión de los indígenas, como la exigencia de la Constitución del Estado mexicano de Occidente de 1825 que suspende el ejercicio de los derechos de ciudadano "por tener costumbre de andar vergonzosamente desnudo", aunque pospone esta exigencia respecto a los indígenas hasta el año $1850^{68}$.

\section{LA SITUACIÓN DESPUÉS DE LA INDEPENDENCIA}

La mayoría de los dominios españoles en América consiguieron la independencia, no sin largas luchas y penosos esfuerzos, en las primeras décadas del siglo XIX. Con ello se produce una auténtica revolución, si consideramos los cambios que se introducen en el ámbito social, político y jurídico. Las nuevas repúblicas se dotan de constituciones que imitan los modelos europeos y norteamericano. El maltrato a los indios durante la conquista y la colonización posterior formó parte del debate ideológico que acompañó a las guerras de independencia. Las nuevas

\footnotetext{
${ }^{66}$ GaRgarella, Roberto, Los fundamentos legales de la desigualdad. El constitucionalismo en América (1776-1860) (Madrid, 2005), p. 57.

${ }^{67}$ Citamos por DE la Torre Villar, Ernesto, La Constitución de Apatzingán y los creadores del Estado mexicano (2a edición, México, 1978), documento 3, p. 138.

${ }^{68}$ Constitución Política del Estado Libre de Occidente (2 de noviembre de 1825), artículo 28, apartado 6. Comprendía el territorio de Sonora y Sinaloa, y había prohibido, en su artículo 4, la esclavitud y "la venta de indios de las naciones bárbaras". Véase: http://biblio.juridicas.unam. $\mathrm{mx} /$ libros/1/271/5.pdf (septiembre 2012).
} 
constituciones hispanoamericanas pusieron fin al tributo indígena, a la mita y a otras formas de trabajo forzoso que recaían exclusivamente sobre los indígenas. Pero, ¿hasta qué punto mejoró la condición jurídica y política de la población indígena como consecuencia de las nuevas constituciones?

Como toda revolución, la que llevó a la independencia de las antiguas colonias españolas en América tuvo actores principales y secundarios, así como clases beneficiadas y perjudicadas. Lo que vamos a defender es que los principales beneficiarios de la emancipación fueron las clases criollas, mientras que los indígenas no vieron mejorada significativamente su situación e incluso, en algunos aspectos, empeoró. La población criolla, o sea, los descendientes de los españoles que habían nacido en América serían los gestores de la independencia. Ellos tenían el control de los cabildos, que desempeñaron un papel estelar en el inicio del proceso emancipador; y dirigían asimismo las milicias, otro factor clave en el desarrollo de las profusas guerras que precedieron a la independencia. Son también criollos quienes firman los numerosos textos constitucionales que consagran la emancipación y quienes disponían de la experiencia política y de la preparación necesaria para llevar a cabo el proyecto ${ }^{69}$.

En los momentos iniciales de la ruptura con la metrópoli se constatan los intereses de ese grupo en algunos hechos muy concretos. Por ejemplo, la Junta Tuitiva de La Paz, constituida el 16 de julio de 1809, cuando el pueblo salió a la calle gritando "Viva Fernando VII, muera el mal gobierno", adoptó entre sus primeras medidas la quema de los libros de la Real Audiencia donde se recogían las deudas con el fisco español ${ }^{70}$.

Son pues las élites criollas, comerciantes y terratenientes, eclesiásticos y militares, las que llevan a cabo el proceso emancipador de la península y las que recurren a las más diversas teorías y razones (el pactum translationis suareciano, el contrato social rousseauniano, la libertad de comercio o el secular maltrato a la población indígena) para legitimar su actuación.

Es revelador que en aquellos países, como en el Perú, donde estaban más recientes los levantamientos indígenas, la independencia llegara más tarde porque no contaba inicialmente con el apoyo de los criollos. Son los criollos, y no los indígenas, quienes acaudillan la revolución, porque ven peligrar sus propios intereses ante la incertidumbre que se vivía en la península ibérica tras la invasión napoleónica. "En Argentina y Venezuela los caudillos de la primera época republicana actuaron como agentes de los intereses latifundistas"71.

Aunque fue muy frecuente la invocación de la opresión secular de los indios

${ }^{69}$ Dealy, Glen, Prolegomena on the Spanish American Political Tradition, en The Hispanic American Historical Review, 48 (1968) 1, pp. 49-50, ha señalado que, de los 468 hombres que firmaron los textos constitucionales que estudia, la inmensa mayoría de ellos habían formado parte de la administración española, y que entre ellos había 92 abogados, 100 miembros del cabildo, 107 en otros cargos burocráticos, 28 militares y 104 clérigos.

${ }^{70}$ Véase: Moreano, Alejandro, La hipótesis española y la Independencia americana, en Revista Casa de las Américas, 259-260 (abril/septiembre 2010), p. 65.

${ }^{71}$ Colom GonzÁlez, Francisco, El trono vacío. La imaginación política y la crisis constitucional de la Monarquía Hispánica, en El Mismo, Relatos de nación. La construcción de las identidades nacionales en el mundo hispánico (Madrid, 2005), p. 49. 
para legitimar la independencia, fueron muy pocos los que pensaron en restablecer la dominación indígena. Entre los escasos defensores de formas políticas monárquicas, dejando aparte las nunca ocultadas del general San Martín, podemos mencionar al general Manuel Belgrano (1770-1820) quien, en su Informe al Congreso de las Provincias Unidas, de julio de 1816, propone el establecimiento de una monarquía en el Río de la Plata, señalando de manera sorprendente que se llame para ocupar el trono a "la dinastía de los incas por la justicia que en sí envuelve la restitución de esta casa tan inicuamente despojada del trono por una sangrienta revolución" 72 .

Este modelo de monarquía temperada se inspiraba en el sistema inglés que algunos independentistas conocieron de primera mano al vivir refugiados en Londres durante mucho tiempo. No hay una única ideología revolucionaria previa, extendida y capaz de provocar la acción independentista, sino que inicialmente fueron los grupos privilegiados de criollos quienes actuaron para evitar caer bajo el dominio francés, organizando juntas, a imitación de las creadas en la Península, y fue el desarrollo de los acontecimientos, a partir de 1810, lo que acabaría llevando a la independencia.

La tesis de Stoetzer es que la revolución americana fue una cuestión hispánica, un guerra entre españoles, con muy escasa participación indígena: "Por cierto, la Revolución nunca involucró ni a los indios ni a los negros, cuya suerte fue mucho mejor en tiempos de la dominación española que después; de ningún modo se beneficiaron de la independencia, ya que bajo el dominio español gozaban de la protección, tanto de la Iglesia como de la Corona"73. Parece un juicio demasiado favorable a los españoles, pero es cierto que quienes inician y llevan a cabo la independencia americana son los "españoles americanos", los criollos.

Otro elemento a considerar es que el papel protagonista recaerá sobre las élites criollas que aúnan el miedo a que Napoleón se apodere de todos los dominios españoles con el temor a perder su situación de privilegio. El miedo a la invasión napoleónica es en América doble, "en primer lugar, el de caer bajo el dominio de la dinastía bonapartista, y, en segundo lugar, a que el punto muerto que está provocando la ausencia del rey dé oportunidad a las clases populares de tomar la iniciativa en este proceso" 74 .

Aunque hay actuaciones concretas de grupos étnicos marginados como los mestizos, mulatos, pardos y negros, las juntas estarán dirigidas por los más importantes grupos sociales. Abogados, militares y eclesiásticos monopolizarán los cargos en las nuevas instituciones. La rebelión no se inicia con el grito revolucionario de igualdad para todos, ni mucho menos con la "libertad de los franceses"

\footnotetext{
${ }^{72}$ Romero, José Luis - Romero, Luis Alberto (editores), Pensamiento político de la emancipación (2a edición, Barcelona, 1985), II, p. 210.

${ }^{73}$ Stoetzer, Carlos, Las raíces escolásticas de la emancipación de la América Española (Madrid, 1982), p. 260. Véase también del mismo autor: El pensamiento político en la América española durante el periodo de la emancipación (1789-1825). Las bases hispánicas y las corrientes europeas (Madrid, 1966).

${ }^{74}$ Chust, Manuel, Un bienio trascendental: 1808-1810, en El Mismo (coordinador), 1808. La eclosión juntera en el mundo hispano (México, 2007), p. 44.
} 
que habían impuesto los haitianos. En las colonias españolas se inicia apelando al monarca español, ya fuera por convencimiento o por interés momentáneo, por parte de las clases más acomodadas de la América hispana. "La marginación de la población indígena del desempeño de oficios públicos en los nuevos Estados nacionales tendrá como consecuencia que su integración en el grupo nacional no se materialice, no alcance ningún grado de realidad, sea un mero discurso sin repercusión práctica"75.

No debe extrañar que esa élite criolla mantuviera parecidos prejuicios contra la población indígena, tanto de clase como de color, como los que habían manifestado los españoles. Españoles peninsulares y españoles americanos habían formado una unidad durante mucho tiempo y comparten las limitaciones propias del pensamiento de la época. Por ejemplo, el liberal español Álvaro Flórez Estrada (1766-1853), en su Examen imparcial de las disensiones de la América con la España, refiriéndose a indios y negros, dice: "Sin educación, sin cultivo alguno de sus facultades intelectuales, $y$, lo que es aún más, sin costumbres, cuando menos era muy dudoso si se les debería conceder desde luego la facultad de tener representación nacional, que no podría servir sino para que todo beneficio recayese en los criollos y europeos"76. La capacidad política de los indios era cuestionada por los españoles peninsulares, porque intentaban reducir la representación americana en la Cortes de Cádiz, pero los mismos prejuicios estaban extendidos entre la población criolla.

Lo que hará cambiar la opinión de los criollos con respecto a los indios está directamente relacionado con el curso de las guerras de independencia. La posición inicial de los indios fue favorable a la Corona. Cuando se creó la Junta de Quito se encontró con la oposición no sólo de los virreyes del Perú y Nueva Granada, sino con la resistencia armada de alguna de sus provincias, entre ellas la de Cuenca que, a finales de 1810 y principios de 1811, luchó contra Quito ayudada por los indios realistas de su provincia. Los indios y los negros, tanto libres como esclavos, fueron utilizados inicialmente por los ejércitos realistas $\mathrm{y}$, más adelante, por los patriotas americanos.

A este cambio de bando de la población indígena contribuyó, sin duda, la adopción de medidas como la prohibición de la mita y la eliminación del tributo indígena, defendidas por los partidarios de la independencia, aunque como es sabido ya había un clima favorable a su supresión desde mucho antes.

Además de su control de los cabildos, otra arma decisiva que estaba en manos de la élite criolla fueron las milicias. En el caso del virreinato del Río de la Plata su actuación fue determinante en todo el proceso emancipador. Estas milicias habían sido creadas para defender Buenos Aires de la invasión británica. La formación de las milicias contribuyó a desarrollar el sentimiento de identidad de los criollos, y

\footnotetext{
${ }^{75}$ Pérez Collados, José María, Las ideas jurídicas: Los juristas iberoamericanos y los procesos de independencia, en Pérez Collados, José María - Rodrigues Barbosa, Samuel (editores), Juristas de la Independencia (Madrid, 2012), p. 27.

${ }^{76}$ Martínez de Pisón Cavero, José María, El pensamiento liberal españoly la independencia de América: Flórez Estrada y Blanco White, en Anuario de Filosofía del Derecho, 27 (2011), p. 153; el autor remite a FlóREz ESTRADA, Álvaro, Examen imparcial de las disensiones de la América con la España (Madrid, 1991), p. 53.
} 
sin ese control militar la metrópoli fue incapaz de recuperar el territorio americano. Pero la presión peninsular fue lo suficientemente fuerte como para que la clase criolla se viera obligada a contar con la población indígena, parda y negra. En el Estatuto Provisional de 1815 de Argentina, se cuenta con los negros para incorporarlos a las milicias: "todo Africano y pardo libre, son soldados cívicos" 77 . En las guerras de independencia ocuparon un papel destacado los libres de color, bastante numerosos en algunos lugares como en el virreinato de Nueva Granada. La utilización de los negros libres, y la promesa de liberar a los negros esclavos que lucharan en el ejército, contribuyeron a que la guerra de independencia se prolongase $^{78}$. La independencia de Colombia, por ejemplo, no fue resultado de una guerra entre los patriotas y el cuerpo expedicionario español, sino una auténtica guerra civil, en el que la población parda y negra fue decisiva para decidir la victoria. La movilización de los negros (libres y esclavos), pardos e indígenas tendrá efectos en las nuevas repúblicas, pero no debe olvidarse que la clase privilegiada seguirá siendo la de los criollos americanos (blancos o mestizos).

Las concesiones legales a estos otros grupos raciales tendrán efectos muy diferentes, en general más beneficiosos para la población negra, pero no tanto para los indígenas americanos. La situación de la población negra tras la independencia, aunque es evidente que pervive la discriminación social, y durante algún tiempo la esclavitud legal, se puede considerar que mejora con las nuevas constituciones. Se declara la supresión de la trata de esclavos y la libertad de vientres para los nuevos nacidos en esos países, y otras medidas de apoyo público para favorecer la manumisión y el buen trato a los todavía esclavos. En algunos casos, como en el Estatuto Provisional de 1815 de Argentina, se les reconocerá un derecho de sufragio, aunque con algunas limitaciones: "Los nacidos en el Pais, que sean originarios por cualquier línea de África, cuyos mayores hayan sido esclavos en este continente, tendrán sufragio activo, siendo hijos de Padres ingenuos; y pasivo los que ya estén fuera del cuarto grado respecto de dichos sus mayores" ${ }^{\prime 9}$. Su situación es ciertamente favorable si se compara con la de los indígenas, pero no debe olvidarse que pagaron un mayor precio por conseguir la independencia de su patria. Simón Bolívar, en su Discurso ante el Congreso de Angostura de 15 de febrero de 1819, se referirá a la "atroz e impía esclavitud que cubría con su negro manto la tierra de Venezuela".

La condenación de la esclavitud estuvo motivada por la inestimable ayudada proporcionada por los negros, libres y esclavos, durante las guerras de emancipación. Los soldados negros, puestos a menudo en primera fila de combate, se ganaron la libertad literalmente con su sangre. En ese mismo "Discurso de Angostura” reconoce Bolívar ese cambio no sólo de la esclavitud a la libertad, sino de bando, porque inicialmente habían sido los realistas quienes incluyeron

\footnotetext{
${ }^{77}$ Estatuto Provisional de Argentina (1815), sección 6a ${ }^{\mathrm{a}}$, cap. $3^{\circ}$, artículo 1.

${ }^{78}$ Almario, Óscar, Del nacionalismo americano en las Cortes de Cádiz al independentismo y nacionalismo de Estado en la Nueva Granada, 1808-1821, en CHUST, Manuel - FrASQUET, Ivana (editores), Los colores de las independencias iberoamericanas. Liberalismo, etnia y raza (Madrid, 2009), p. 212, refiriéndose a Nueva Granada dice que "los indios no fueron incorporados al Ejército Libertador y los negros lo fueron con ciertas reservas y como carne de cañón”.

${ }^{79}$ Estatuto Provisional de Argentina (1815), sección $1^{\mathrm{a}}$, cap. $3^{\circ}$, artículo 7.
} 
en sus filas a los negros: "La esclavitud rompió sus grillos, y Venezuela se ha visto rodeada de nuevos hijos, de hijos agradecidos que han convertido los instrumentos de su cautiverio en armas de libertad"80.

Si la élite criolla, y en menor medida la población negra, mejoró su situación, en cambio, la población indígena empeoró tras la emancipación. El 4 de julio de 1825 Bolívar decretó el reparto de tierras entre los indígenas, así como la abolición de la jurisdicción propia de los caciques. Los indios quedan asimilados al resto de los ciudadanos y se suprimen las cargas personales que recaían sobre ellos.

Pero, la igualación legal, al ser considerados formalmente como iguales, empeoró su situación de hecho. Perdieron autonomía y perdieron el control de sus tierras comunales. Las "Leyes de Indias" habían permitido la conservación de los sistemas propios de designación de sus jefes naturales. "Cuando las fuerzas republicanas se impusieron en las regiones realistas, las comunidades indígenas fueron las que sufrieron el peso de la derrota" $"$. La nueva legislación autorizaba a cualquier ciudadano a residir en las antiguas "repúblicas de indios", lo que facilitó la expropiación de sus tierras. "El hecho de que se anulara el estatus legal inferior de los indios, concediéndoles igualdad jurídica, importaba poco en vista de las relaciones de poder y los resentimientos raciales y culturales de los liberales" 82 .

La Corona y la Iglesia, aunque fuera con políticas paternalistas, habían representado un apoyo para la población indígena, que se pierde al considerarles simplemente como nacionales iguales cuando se produce la independencia sin tomar medidas para hacer real esa igualdad formal.

Durante las guerras de independencia los indígenas estuvieron, al menos inicialmente, en el bando realista. No tenían mucho interés en sustituir a los españoles peninsulares por los americanos. En aquellos reinos donde había una fuerte mayoría indígena no veían éstos con buenos ojos la independencia, porque percibían que las élites criollas más cercanas podrían ser peores amos que los españoles peninsulares, más alejados. La igualación que supuso la independencia tenía un aspecto claramente positivo para los criollos y para otras clases como las mestizas y negras. Se establecía una igualdad jurídica, la supresión de la nobleza, de los tratamientos y de los privilegios, pero para los indígenas ese régimen de igualdad no mejoraría su situación real. Los indígenas vieron reducida su autonomía y fueron obligados a regirse con los mismos mecanismos que el resto de la población.

Aunque con limitaciones, la legislación indiana había permitido la conservación del Derecho tradicional indígena: "Ordenamos y mandamos que las leyes y buenas costumbres, que antiguamente tenian los Indios para su buen gobierno $y$ policía, y sus usos y costumbres observadas y guardadas después que son Christianos, $y$ que no se encuentran con nuestra Sagrada Religión, ni con las leyes de este libro, y las

${ }^{80}$ Bolívar, Simón, Doctrina del Libertador (3a edición, Caracas, 1985), p. 124.

${ }^{81}$ Lasso, Marixa, Población y sociedad, en Bravo García, Javier (coordinador), Colombia, I: 1808/1830. Crisis imperial e independencia (Madrid, 2010), p. 223.

${ }^{82}$ Miño Grijalva, Manuel, El proceso económico, en Hernández Chávez, Alicia (directora), México, I: 1808-1830. Crisis imperial e independencia (Madrid, 2011), p. 179. 
que han hecho y ordenado de nuevo se guarden y executen" $"$. Los españoles habían respetado a los caciques indios, a los que utilizaban para facilitar su dominación, por lo que traspasaron a la población indígena parecidas categorías estamentales a las que conocían en España. De ahí el respeto para los caciques, que estaban exentos de trabajar y pagar impuestos. Los indios disponían de una legislación especial, paternalista y pretendidamente favorable en la intención. En algunos casos se puede hablar de auténticos privilegios, como el que tenían los indios de Tlaxcala, que "gozaban del singular privilegio de que ningún español, ya criollo ya europeo, tuviera derecho a formar parte del cabildo de la ciudad, lo que todavía da por vigente Humboldt al visitar Tlaxcala a principios del siglo XIX" ${ }^{\prime 4}$.

El mantenimiento de sus propias autoridades era una garantía básica de autonomía y respeto a su tradición cultural. Los españoles respetaron los sistemas de elección de los caciques, incluidos los hereditarios. Pero los cargos perpetuos resultarán totalmente incompatibles con la nueva filosofía igualitaria impuesta por las constituciones que llevan a cabo la emancipación. Para liberales y republicanos el cacique no podía dejar de aparecer como un déspota local que debía desaparecer. No se puede decir que los españoles peninsulares defendieran de manera convencida esa situación, que en parte se debía a la dificultad, provocada por la inmensa distancia, de imponer una legislación uniforme.

Pero las nuevas autoridades criollas tras la independencia estaban mucho más cerca, iban a ser más efectivas, y no permitirían diferencias culturales que consideraban como una rémora para el progreso. Pedro Fermín de Vargas (1762-1810), precursor de la emancipación de Colombia, en su Memoria sobre la población del Reino de Nueva Granada, muestra una pésima opinión sobre los indios cuya rápida desaparición desea mediante el mestizaje: "Para aumento de nuestra agricultura sería igualmente necesario españolizar nuestros indios [...] sería muy de desear que se extinguiesen los indios, confundiéndolos con los Blancos" ${ }^{\prime 5}$. Se trata pues de criollos que tienen una actitud ante los indios no muy diferente de la que habían mantenido los españoles durante la colonia.

La enorme diferencia entre ricos y pobres había sido uno de los factores de la inestabilidad característica del dominio español en América. Así lo entendieron algunos de los que reflexionaron en ese momento sobre las causas de la independencia. Para el asturiano, y obispo de Michoacán, don Manuel Abad y Queipo (1751-1825), la emancipación de la Nueva España no puede entenderse sin tener en cuenta "el enorme desnivel económico entre los muy ricos y los extremadamente pobres", aunque asimismo toma en cuenta "el aislamiento e incultura de los

${ }^{83}$ Recopilación de Leyes de los Reinos de las Indias, lib. II, tít. $1^{\circ}$, ley $4^{\mathrm{a}}$. Citamos por la edición facsímil de la 4a impresión, Madrid, viuda de D. Joaquín Ibarra, 1791 (Madrid, 1998), I, p. 218.

${ }^{84}$ Madariaga, Salvador de, Cuadro histórico de las Indias. Introducción a Bolivar (Buenos Aires, 1950), p. 59. El privilegio más conocido de la población de Tlaxcala fue el de no pagar impuestos en recompensa a su ayuda en la conquista de México. Tampoco aquí se respetó lo pactado por Cortés, porque el privilegio duró veinte años y no perpetuamente como se les había prometido. Véase: Cruz BARneY, Óscar, Historia del Derecho indiano (Valencia, 2012), p. 209.

${ }^{85}$ Gómez Hoyos, Rafael, cit. (n. 39), I, p. 282. 
indios aplastados por la viciosa aplicación de sus leyes privilegiadas, a la infancia legal de las castas mestizas que les impide situarse socialmente”, y también a los abusos de las autoridades públicas ${ }^{86}$.

Así identificados los males que había que extirpar, cuando se produce la emancipación se hacen todos los esfuerzos posibles para igualar a los indígenas con el resto de la población. Pero la igualación legal no fue acompañada de las medidas necesarias para hacerla efectiva, lo que se tradujo de hecho en un empeoramiento de la situación de los indios. La igualdad legal no se concretó en una mayor protección jurídica, ni en una mejora económica, ni en una mayor participación política. La autonomía económica y organizativa de las comunidades indígenas será vista, por una parte, como una amenaza a la soberanía de los nuevos Estados independientes -como lo había sido para el absolutismo de la Monarquía borbónica-, pero, por otra, como la principal rémora a la mejora de la actividad económica. Refiriéndose a la Nueva España, asegura Pérez Collados que "tanto para el liberalismo decimonónico mexicano, como antes para los proyectos ilustrados metropolitanos, las comunidades indígenas eran una traba para el establecimiento del mercado libre y el desarrollo de la prosperidad" 87.

Los indios debían ser integrados en el mercado, y para ello era preciso que dejaran de ser "indios" y fueran propietarios, consumidores y contribuyentes. Es cierto que se prohíbe el "empleo gratuito" de los indios en cualquier servicio personal, pero no se reconoce una "equiparación política del indio con la del ciudadano" por lo que se refiere a los derechos políticos ${ }^{88}$. Legalmente los indios serán peruanos, colombianos o mexicanos, pero la realidad atestiguaba el mantenimiento de múltiples desigualdades con respecto a los demás nacionales.

La igualación de los indios tampoco mejoró su situación fiscal. Desde el punto de vista tributario, los indios fueron obligados al pago de los mismos impuestos que el resto de ciudadanos, incluidos aquellos de los que estaban exentos en la época colonial ${ }^{89}$.

Durante la colonia el pago de impuestos por parte de los indios se había visto favorecido por el hecho de permitir su pago en especie, pero la nueva economía liberal obligará al pago en metálico. Por una parte, en el momento de la inde-

\footnotetext{
${ }^{86}$ Citamos por Giménez Fernández, Manuel, Las doctrinas populistas en la independencia de Hispano-América (Sevilla, 1947), pp. 75-76.

${ }^{87}$ Pérez Collados, José María, Las tierras comunales en los pueblos de indios y su trayectoria en el México independiente, en De Dios, Salustiano - Infante, Javier - Robledo, Ricardo - ToRIJANO, Eugenia (coordinadores), Historia de la propiedad en España. Bienes comunales, pasado $y$ presente (Madrid, 2002), p. 379.

${ }^{88}$ Andrés García, Manuel, La construcción del Estado nacional en Perú y la marginación política indigena (Siglo XIX) (Santa María de la Rábida, Universidad Internacional de Andalucía, 2007), pp. 72-73. Considera este autor significativo el que las proclamas del Libertador que prohibían el trabajo gratuito de los indios no fueran traducidas al quechua. Consultado en: http://dspace.unia.es/handle/10334/43 (mayo 2013).

${ }^{89}$ Señala Serrera, Ramón María, Sociedad estamental y sistema colonial, en Annino, A. - Castro Leiva, L. - Guerra, F.-X. (directores), De los imperios a las naciones: Iberoamérica (Zaragoza, 1994), p. 56, que, como norma general, los indios estaban "eximidos igualmente de pagar diezmos y alcabalas".
} 
pendencia, el montante del "tributo de indios" no era muy alto en el conjunto de los impuestos coloniales. En los últimos años que precedieron a la revolución en el Virreinato de Nueva Granada, el tributo indígena era de 47.000 pesos. En ese mismo momento el monopolio del tabaco representaba diez veces más, 470.000 pesos, siendo el importe total de los tributos del reino neogranadino cercano a los dos millones y medio ${ }^{90}$. Cantidades considerables procedían de las alcabalas, tasas de aduanas, quinto de la extracción de metales, acuñación de moneda, diezmos y papel sellado. Sin embargo, la principal fuente de ingresos en el momento de la emancipación procedía de los estancos del tabaco y el aguardiente.

La supresión del tributo personal sobre los indios sería una de las medidas más significativas de las nuevas constituciones en las que se plasmaba la independencia de las antiguas colonias hispanoamericanas. La medida había sido aprobada por los liberales, tanto españoles como americanos, en las Cortes de Cádiz. Cuando algunas Juntas ya independentistas (en Río de la Plata y Venezuela) enarbolaron como bandera la supresión del tributo indígena, entonces los realistas pensaron que les sería políticamente favorable el apostar también por su anulación. El impuesto personal sobre los indios fue formalmente abolido el 13 de marzo de 1811. Es interesante constatar que, cuando Fernando VII vuelve a restablecer el absolutismo y declara derogadas no sólo la Constitución de Cádiz, sino toda la legislación liberal concomitante, sin embargo, con respecto al tributo de indios aparece una clara indecisión, se pospone la medida, y, cuando se acepta, se hace con muchas reservas, restableciéndole sólo "en aquellas regiones que lo solicitaran"

La indecisión con respecto a esta medida no fue exclusiva del gobierno peninsular español, sino que, también en las antiguas colonias hispanoamericanas, hubo sus retrocesos. Por ejemplo, en Venezuela, después de haber sido suprimido el tributo indígena por la ley de 11 de octubre de 1821, la permanente crisis hacendística hizo que Bolívar lo recuperara en 1828. El general San Martín suprimió el tributo indígena para el recién liberado territorio del Perú el 27 de agosto de 1821. Sin embargo, lo cierto es que la desaparición definitiva del tributo no se produjo en el Perú hasta el 5 de julio de 1854 con el Presidente Ramón Castilla. De todas las medidas adoptadas sobre la población indígena por las nuevas constituciones que estatuyen la independencia, la que tuvo a largo plazo consecuencias más graves para los indígenas fue la decidida voluntad de dividir sus propiedades comunales. "La ficción de igualdad tuvo consecuencias negativas para la propiedad indígena" 92 .

La supresión de los tributos específicos indígenas fue acompañada de una expropiación masiva de sus tierras comunales, lo que acabaría favoreciendo la creación de latifundios. Con respecto a la propiedad, la igualación fue el mecanismo

\footnotetext{
${ }^{90}$ Restrepo, José Manuel, Historia de la Revolución de la República de Colombia (Medellín, 1969), I, p. 29.

${ }^{91}$ Costeloe, Michael P., La respuesta a la independencia. La España imperial y las revoluciones hispanoamericanas, 1810-1840 (1986, traducción castellana México, 2010), p. 154.

${ }^{92}$ Levaggi, Abelardo, Tratamiento legal y jurisprudencial del aborigen en la Argentina durante el siglo XIX, en EL MISMO (coordinador), El aborigen y el derecho en el pasado y el presente (Buenos Aires, 1990), p. 256.
} 
que permitió apropiarse de muchas tierras indígenas. La libertad de movimientos que se reconocía en las nuevas constituciones hizo llegar más población blanca y mestiza a los poblados indios. El reparto de las tierras comunes de los indios obedecía a la lógica liberal que confía en la propiedad privada como un instrumento básico para la reactivación económica. Pero, paradójicamente, parte de las tierras comunales de los indígenas van a ser vendidas a los hacendados criollos que las dedican a la agricultura y ganadería extensivas, lo que reducirá su producción. Los efectos de este reparto de la propiedad fueron negativos para la población indígena porque, de hecho, se permitía la expropiación de una buena parte de sus propiedades. Se repartieron las tierras comunales entre los indios, pero sólo se les concedieron aquellos terrenos que podían cultivar "directamente", para de ese modo poder vender los "restantes" terrenos comunales. Se negaba así a los indios el derecho a que fueran arrendadores de sus tierras. Otra limitación frecuentemente impuesta fue la de prohibir la venta de los terrenos repartidos a los indios durante un tiempo, a veces de hasta veinte años, lo que devaluaba su propiedad ${ }^{93}$.

En conclusión, la independencia no supuso un reconocimiento de los derechos de las comunidades indígenas ni una mejora de la situación de los indios, sino que el individualismo propio del pensamiento liberal se concretó en la venta forzosa de las propiedades comunales y también en un incremento de la asimilación a la cultura dominante. Ivana Frasquet es contundente: "Las capas populares indígenas, castas mulatas y negras, participaron de la revolución pero no de la consecución de sus logros"94. Una vez más se impuso la evidencia histórica de que para los explotados no suele comportar ninguna ventaja el tener a los amos más cerca. La retórica de la igualdad ante la ley y la libertad política plasmada en las constituciones hispanoamericanas, por lo que se refiere a la población indígena, resultó tan estéril como las consabidas muletillas con que las Leyes de Indias, al imponer las encomiendas o la mita, insistían en que se atendiera "al buen tratamiento de los naturales".

\section{BiBLIOGRAFÍA}

Almario, Óscar, Del nacionalismo americano en las Cortes de Cádiz al independentismo y nacionalismo de Estado en la Nueva Granada, 1808-1821, en CHUST, Manuel - FRASQUET, Ivana (editores), Los colores de las independencias iberoamericanas. Liberalismo, etnia y raza (Madrid, 2009).

Andrés García, Manuel, La construcción del Estado nacional en Perú y la marginación

${ }_{93}^{9}$ En un decreto de Bolívar, expedido en El Rosario de Cúcuta el 20 de mayo de 1820, donde se dictan normas para restablecer en sus derechos a los indígenas, después de permitir el reparto de sus tierras, se les prohíbe que arrienden los lotes que les hayan tocado "sin conocimiento del juez politico para evitar los daños y fraudes que se les causaren”" [BOLÍvar, Simón, cit. (n. 80), p. 141]. En el decreto del mismo Bolívar, de 4 de julio de 1825, dado en el Cuzco se dispone también la distribución de tierras a los indígenas "con la limitación de no poderlos enajenar hasta el año 50 y jamás a favor de manos muertas” (Ibíd., p. 202).

${ }^{94}$ FrasQUet, Ivana, en ChUST, Manuel (editor), Las independencias iberoamericanas en su laberinto. Controversias, cuestiones, interpretaciones (Sevilla, 2010), p. 150. 
política indígena (Siglo XIX) (Santa María de la Rábida, Universidad Internacional de Andalucía, 2007).

Bolívar, Simón, Doctrina del Libertador (3a edición, Caracas, 1985).

Chust, Manuel (editor), Las independencias iberoamericanas en su laberinto. Controversias, cuestiones, interpretaciones (Sevilla, 2010).

Chust, Manuel, Un bienio trascendental: 1808-1810, en El Mismo (coordinador), 1808. La eclosión juntera en el mundo hispano (México, 2007).

Clavero, Bartolomé, Ama Llunku, Abya Yala: Constituyencia indigena y Código ladino por América (Madrid, 2000).

Colom GonzÁlez, Francisco, El trono vacío. La imaginación política y la crisis constitucional de la Monarquia Hispánica, en El Mismo, Relatos de nación. La construcción de las identidades nacionales en el mundo hispánico (Madrid, 2005).

Costeloe, Michael P., La respuesta a la independencia. La España imperialy las revoluciones hispanoamericanas, 1810-1840 (1986, traducción castellana México, 2010).

Cruz Barney, Óscar, Historia del Derecho indiano (Valencia, 2012).

DE la Torre Villar, Ernesto, La Constitución de Apatzingán y los creadores del Estado mexicano (2a edición, México, 1978).

DE LUCAS, Javier Sobre algunas dificultades de la noción de derechos colectivos, en ANSUÁTEGUI RoIG, Francisco Javier (editor), Una discusión sobre derechos colectivos (Madrid, 2001).

DeAly, Glen, Prolegomena on the Spanish American Political Tradition, en The Hispanic American Historical Review, 48 (1968) 1.

Flórez Estrada, Álvaro, Examen imparcial de las disensiones de la América con la España (Madrid, 1991).

García Giráldez, Teresa, El pensamiento politico liberal centroamericano del siglo XIX: José Cecilio del Valle y Antonio Batres Jáuregui, en Revista Complutense de Historia de América, 35 (2009).

GaRgarella, Roberto, Los fundamentos legales de la desigualdad. El constitucionalismo en América (1776-1860) (Madrid, 2005).

Giménez Fernández, Manuel, Las doctrinas populistas en la independencia de HispanoAmérica (Sevilla, 1947).

Gómez Hoyos, Rafael, La revolución granadina de 1810. Ideario de una generación y de una época (1781-1821) (Bogotá, 1962), I.

Grases, Pedro (compilador), Pensamiento político de la emancipación venezolana (Caracas, 1988).

GRASES, Pedro, La conspiración de Gual y España y el ideario de la independencia (Buenos Aires, 1949).

KInG, James, The Colored Castes and American Representation in the Cortes of Cádiz, en Hispanic American Historical Review, 33 (1953).

Lasso, Marixa, Población y sociedad, en Bravo García, Javier J. (coordinador), Colombia, I: 1808/1830. Crisis imperial e independencia (Madrid, 2010).

LeVAGGI, Abelardo, Tratamiento legal y jurisprudencial del aborigen en la Argentina durante el siglo XIX, en EL Mismo (coordinador), El aborigen y el derecho en el pasado y el presente (Buenos Aires, 1990).

MaDARIaGa, Salvador de, Cuadro histórico de las Indias. Introducción a Bolivar (Buenos Aires, 1950).

Martínez de Pisón Cavero, José María, El pensamiento liberal español y la inde- 
pendencia de América: Flórez Estrada y Blanco White, en Anuario de Filosofía del Derecho, 27 (2011).

Matienzo, Juan, Gobierno del Perú con todas las cosas pertenecientes a él y a su historia (1567, reimpresión París/Lima, 1967).

Miño Grijalva, Manuel, El proceso económico, en Hernández Chávez, Alicia (directora), México, I: 1808-1830. Crisis imperial e independencia (Madrid, 2011).

Montesquieu, Ch., De l'esprit des lois (1748, Paris, 1878).

Moreano, Alejandro, La hipótesis española y la Independencia americana, en Revista Casa de las Américas, 259-260 (abril/septiembre 2010).

Orlando Melo, Jorge, Documentos constitucionales colombianos, 1810-1815, en: http:// www.jorgeorlandomelo.com/bajar/documentosconstitucionales1.pdf

Pérez Collados, José María, Las ideas jurídicas: Los juristas iberoamericanos y los procesos de independencia, en Pérez Collados, José María - Rodrigues Barbosa, Samuel (editores), Juristas de la Independencia (Madrid, 2012).

Pérez Collados, José María, Las tierras comunales en los pueblos de indios y su trayectoria en el México independiente, en De Dios, Salustiano - Infante, Javier - Robledo, Ricardo - TorijANo, Eugenia (coordinadores), Historia de la propiedad en España. Bienes comunales, pasado y presente (Madrid, 2002).

Recopilación de Leyes de los Reinos de las Indias, citada por la edición facsímil de la $4^{\mathrm{a}}$ impresión, Madrid, viuda de D. Joaquín Ibarra, 1791 (Madrid, 1998), I.

Restrepo, José Manuel, Historia de la Revolución de la República de Colombia (Medellín, 1969), I.

Reyes, Catalina, La ambigüedad entre lo antiguo y lo nuevo. Dos mundos que se entrecruzan: Nueva Granada, 1808-1810, en CHust, Manuel (coordinador), Doceañismos, constituciones e independencias. La Constitución de 1812 y América (Madrid, 2006).

Romero, José Luis - Romero, Luis Alberto (editores), Pensamiento politico de la emancipación (2a edición, Barcelona, 1985), II.

San Martino de Dromi, Ma Laura (editora), Documentos constitucionales argentinos (Buenos Aires, 1994).

Serrera, Ramón María, Sociedad estamental y sistema colonial, en AnNinO, A. - CASTRO LeIVA, L. - Guerra, F.-X. (directores), De los imperios a las naciones: Iberoamérica (Zaragoza, 1994).

Simmons, Merle, La revolución norteamericana en la independencia de Hispanoamérica (Madrid, 1992).

Stoetzer, Carlos, El pensamiento político en la América española durante el periodo de la emancipación (1789-1825). Las bases hispánicas y las corrientes europeas (Madrid, 1966).

Stoetzer, Carlos, Las raices escolásticas de la emancipación de la América Española (Madrid, 1982).

Torres Tenorio, Camilo, Representación del Cabildo de Santa Fe a la Junta Central de España (20 de noviembre de 1809) (Bogotá, 1960). 
